\title{
Photoinhibition of marine nitrifying bacteria. I. Wavelength-dependent response
}

\author{
Maria A. Guerrero, Ronald D. Jones* \\ Southeast Environmental Research Program and Department of Biological Sciences, Florida International University, \\ University Park, Miami, Florida 33199, USA
}

\begin{abstract}
Axenic cultures of chemolithotrophic nitrifying bacteria $\left(\mathrm{NH}_{4}{ }^{+}\right.$and $\mathrm{NO}_{2}^{-}$oxidizers) respond to light in distinct manners. After short-term ( 2 to $4 \mathrm{~h}$ ) monochromatic irradiations both types of nitrifying bacteria demonstrated a widespread photosensitivity in the near-UV region (300 to $375 \mathrm{~nm}$ ) and a differential photosensitivity in the blue region of the spectrum ( 400 to $475 \mathrm{~nm}$ ). Nitrite oxidizers were less sensitive overall to blue light inhibition than were ammonium oxidizers. Characteristically, the extent of the photoinhibition was species-specific and light response was dose- and wavelength-dependent. Photoprotection by higher substrate concentrations was only observed with ammonium oxidizers. Increased cell densities altered the phototolerance of nitrite oxidizers and made these organisms light-susceptible. Similarly, treatment with a low light dose for extended periods was more damaging to nitrite oxidizers, when high cell densities were used. Polychromatic irradiations served to confirm the monochromatic results. Cool-white fluorescent light inhibited $\mathrm{NH}_{4}{ }^{+}$oxidizing activity but not $\mathrm{NO}_{2}{ }^{-}$oxidizing activity. Exposure to sunlight resulted in inhibition of activity in both types of nitriflers. These data demonstrate that the effect of light on autotrophic nitrification depends not only on the type of nitrifier $\left(\mathrm{NH}_{4}{ }^{+}\right.$or $\mathrm{NO}_{2}{ }^{-}$oxidizer), but also on the conditions of their environment.
\end{abstract}

KEY WORDS: Nitrification · Photonhıbition · Nitrifying bacterla

\section{INTRODUCTION}

Nitrification constitutes the only biological mechanism for the conversion of $\mathrm{NH}_{4}{ }^{+}$to $\mathrm{NO}_{3}{ }_{3}^{-}$. Much of the earlier work on factors affecting nitrification $\left(\mathrm{NH}_{4}{ }^{+}\right.$and $\mathrm{NO}_{2} \cdot$ oxidation) was done with soil nitrifying bacteria because of their agricultural importance (Focht \& Verstraete 1977). These works established that light can regulate the process of nitrification as it can inhibit both ammonium and nitrite oxidizing activities (Müller-Neuglück \& Engel 1961, Schön \& Engel 1962). Light impact on nitrification gains importance in aquatic systems, since in these systems light penetration can occur to different depths (Jerlov 1968, Craig 1973. Gieskes et al. 1989) depending on the water transparency. Thus, along with the usual environmental limitations, such as substrate availability, $\mathrm{pH}, \mathrm{pO}_{2}$, and temperature, aquatic nitrifiers face the additional

\footnotetext{
-Addressee for correspondence. E-mail: serp@servax.fiu.edu
}

stress of light. Thus far, there have been contrasting results as to which step of the process is more photosensitive. Olson (1981), Yoshioka \& Saijo (1984), and Diab \& Shilo (1988) have reported nitrite oxidation as being especially sensitive to light in oceanic, freshwater and aquaculture ponds, respectively. However, Vanzella et al. (1989) described ammonium oxidation as the step most affected by light using pure cultures and marine samples. Horrigan \& Springer (1990) reported dissimilar photosensitivities in $\mathrm{NH}_{4}{ }^{+}$oxidizers from different habitats (estuarine and marine). Among the reasons that may have contributed to the apparent differences in results are the facts that some workers used natural populations as opposed to pure cultures that different light sources and intensities were used, and that the species tested and incubation conditions used were different. For comparison purposes, the present work used 4 representative marine species to examine the photoresponse of both ammonium and nitrite oxidizers, under standardized conditions. In addition, variables such as substrate concentration, 
light intensity, light quality (wavelength), dose rate and cell density were considered, since these factors can vary naturally. Ecological consequences of the light sensitivity in this 2 -step process are discussed.

\section{MATERIALS AND METHODS}

Microorganisms and growth conditions. The marine ammonium oxidizing bacteria Nitrosomonas cryotolerans (ATCC 49181, Jones et al. 1988) and Nitrosococcus oceanus (ATCC 19707) were grown axenically in dark $2 \mathrm{l}$ chemostat culture units (dilution rate, $0.1 \mathrm{~d}^{-1}$ ). The $\mathrm{pH}$ was adjusted automatically and maintained at $7.8 \pm 0.1$ by the addition of sterile $5 \%$ $\mathrm{K}_{2} \mathrm{CO}_{3}$. The medium for ammonium oxidizers (Jones \& Hood 1980) contained $12 \mathrm{mM}_{\text {of }} \mathrm{NH}_{4}{ }^{+}$as $\left(\mathrm{NH}_{4}\right)_{2} \mathrm{SO}_{4}$ at a salinity of $30 \%$ adjusted by the addition of Instant Ocean Synthetic Sea Salts (Aquarium Systems, Mentor, OH, USA).

The marine nitrite oxidizing bacteria Nitrococcus mobilis (ATCC 25380) and Nitrobacter sp. (Nb 297, provided by S. W. Watson) were grown in the same manner in the medium of Watson \& Waterbury (1971). $\mathrm{pH}$ was adjusted automatically and maintained at $7.5 \pm$ 0.5 by injecting filter sterilized $(0.2 \mu \mathrm{m}) \mathrm{CO}_{2}$. The medium for nitrite oxidizers contained $30 \mathrm{mM}$ of $\mathrm{NO}_{2}$ as $\mathrm{NaNO}_{2}$. All cultures were constantly aerated, mixed with a magnetic stirring bar and kept at a constant temperature of $25^{\circ} \mathrm{C}$

Preparation of standard cell suspension. Cells $(100 \mathrm{ml})$ were harvested by centrifugation $(10000 \times g$, $15 \min , 5^{\circ} \mathrm{C}$ ) from chemostat units. The cell pellet was washed twice with $0.2 \mu \mathrm{m}$ filtered sea water (FSW), $\mathrm{pH} 7.8$. The sea water used was low enough in nutrients that it did not have any consequence on the results (concentrations of $\mathrm{NH}_{4}{ }^{+}, \mathrm{NO}_{2}{ }^{-}$and $\mathrm{NO}_{3}{ }^{-}$were below $20 \mathrm{nM}$ ). Cell densities were assessed with a Petroff-Hauser counting chamber and were made up to vary from $1 \times 10^{5}$ to $1 \times 10^{7}$ cells $\mathrm{ml}^{-1}$, depending on the experiment.

Description of illumination system. A $1 \mathrm{~kW}$ xenon (short-arc) lamp (Optical Radiation Corp., Azusa, CA, USA) enclosed in an LH $151 \mathrm{~N}$ lamp housing (Spectral Energy Corp., Hillsdale, NJ, USA) was used as a light source. This high-intensity light beam was focused through a GM-252 1/4 monochromator (Spectral Energy Corp. into the sample compartment. The tunable GM-252 monochromator had adjustable slits to control entrance, height and width of the light beam. Entrance slit was set according to the light intensity required ( 0 to $0.6 \mathrm{~mm}$ ): slit height was set at $6.5 \mathrm{~mm}$ and the exit slit was set to allow a $20 \mathrm{~nm}$ bandpass. Transmitted light quality and quantity were determined by wavelength scans using a $1 / 4$ monochroma- tor Model 77200 (Oriel Corp., Stratford, CT, USA) attached to a photodiode detection system Model 7072 (Oriel Corp.). The voltage signal from the detector was converted to radiometric units by using a 78250 Voltage Radiometry Board (Oriel Corp.) that interfaced with the PC-based detection system. The radiometric measurements were checked against potassium ferrioxalate actinometry (Hatchard \& Parker 1956).

Monochromatic illumination of cells. Cylindrical quartz cuvettes (light path, $100 \mathrm{~mm}$ ) were used to hold the volume of cell suspension to be irradiated. The total volume including cuvette $(30 \mathrm{ml})$ and pump tubing $(9 \mathrm{ml})$ was $39 \mathrm{ml}$. Considering this volume was kept under continuous flow $\left(14 \mathrm{ml} \mathrm{min}^{-1}\right.$; Ismatec 4 channel pump), it was assumed that each cell was directly in the light path for only $1 / 3$ of the total time of irradiation. The cuvettes were initially filled with FSW that contained the substrate at the desired concentration for the test. Once the cuvettes were filled, the pump was started and the outside reservoirs were filled to a constant level for all the experiments. The design allowed for the FSW (with substrate) to go first through a refrigerated circulator (Haake A81) that kept the entire system at $20^{\circ} \mathrm{C}$ during the irradiations, and then back into the sample compartment.

Once temperature was stable, a $0.2 \mathrm{ml}$ portion of the standard cell suspension was inoculated into each of the 2 reservoirs (experimental and control). Therefore, the cell suspension to be irradiated consisted of FSW. the substrate of interest $\left(\mathrm{NH}_{4}{ }^{+}\right.$or $\left.\mathrm{NO}_{2}{ }^{-}\right)$at the appropriate final concentrations (10 to $100 \mathrm{\mu M} \mathrm{NH}_{4}{ }^{+}$or 2 to $\left.5 \mu \mathrm{M} \mathrm{NO}_{2}{ }^{-}\right)$and the microorganisms $\left(\mathrm{NH}_{4}{ }^{+}\right.$or $\mathrm{NO}_{2}{ }^{-}$ oxidizers). No additional buffering agent was included since the low cell densities used in these experiments along with the short irradiation periods did not significantly alter the $\mathrm{pH}$ of the cell suspension. This was confirmed by measuring $\mathrm{pH}$ of the cell suspension before and after irradiation. After inoculation of the cuvettes, 2 min were allowed for obtaining an even distribution of the cells in the cuvette and sampling reservoir under the flow conditions used. The monochromator's exit slit was then opened to start the irradiation period. At this point, the time $0\left(T_{0}\right)$ samples were collected, and the timing for the total irradiation period was initiated. For the purpose of sampling at different time intervals, the system was kept open to the atmosphere, which also had the advantage of providing saturating $\mathrm{O}_{2}$ conditions and no accumulation of photochemically formed $\mathrm{CO} \quad(<0.3 \mathrm{nM})$. The light intensities ranged from 5 to $25 \mathrm{~W} \mathrm{~m}^{-2}$.

Polychromatic illumination of cells. Sunlight: Conditions of flow, temperature, and cell suspension composition were kept the same as in the laboratory set-up described above. The control cuvette and tubing were appropriately wrapped with aluminum foil while the 
experimental cuvette and tubing were left exposed to sunlight. Light intensity was measured in this case with an IL 1700 research radiometer. Sunlight irradiance during the experiments ranged from 360 to $400 \mathrm{~W}$ $\mathrm{m}^{-2}$ (400 to $1100 \mathrm{~nm}$ ).

Cool-white fluorescent irradiation: For these experiments daylight (cool-white) fluorescent tubes (General Electric F15T8/CW) were used. Two tubes were placed diagonally opposing on each side of the chemostat bottle. The fluorescent lamps were connected to a $24 \mathrm{~h}$ timer, which permitted simulation of day-night cycles (i.e. 12:12 h light:dark; 8:16 h light:dark). These experiments were conducted after the chemostats had reached steady state (i.e. constant nitrite concentration, approx. 4 volume changes), but before visible cell attachment to the vessel walls occurred. Twenty $\mathrm{ml}$ of chemostat culture was harvested by centrifugation $\left(10000 \times g, 15 \mathrm{~min}, 5^{\circ} \mathrm{C}\right)$, washed twice with FSW and resuspended in $1 \mathrm{ml}$ of FSW. From this cell suspension $10 \mu \mathrm{l}$ was taken and diluted into $10 \mathrm{ml}$ of distilled water to determine nitrite concentrations. The $\mathrm{pH}$ was also measured at the different sampling times

Action spectra. The following conditions were used for action spectroscopy: light intensity $25 \mathrm{~W} \mathrm{~m}^{-2}$; final substrate concentration $100 \mu \mathrm{M} \mathrm{NH}_{4}^{+}$and $2 \mu \mathrm{M} \mathrm{NO}_{2}{ }^{-}$; and cell density $10^{6}$ cells $\mathrm{ml}^{-1}$. Irradiation times were selected on the basis of time course experiments (see below, 'Results') as 2 and $4 \mathrm{~h}$ for $\mathrm{NH}_{4}{ }^{+}$and $\mathrm{NO}_{2}{ }^{-}$oxidizers, respectively. Monochromatic irradiations were done in $25 \mathrm{~nm}$ increments that started with light of $300 \mathrm{~nm}$ and ended at $500 \mathrm{~nm}$. Above $500 \mathrm{~nm}$ there was no detectable photoinhibition (see Fig. 2A, B).

Other variables tested. Substrate concentration: Final substrate concentrations of $\mathrm{NH}_{4}{ }^{+}$or $\mathrm{NO}_{2}{ }^{-}$were adjusted by adding an appropriate amount from $10 \mathrm{mM}$ stock solutions of $\left(\mathrm{NH}_{4}\right)_{2} \mathrm{SO}_{4}$ or $\mathrm{NaNO}_{2}$, respectively.

Cell density: Cell suspensions were made up to an appropriate cell density by increasing or decreasing the final resuspension volume with FSW, and confirming the preestimated cell number by microscopic counts.

Cell product assay: After 2 h of monochromatic irradiation $1 \mathrm{ml}$ was collected from each reservoir (experimental and control) and was added to $60 \mathrm{ml}$ serum bottles that contained $10 \mathrm{ml} \mathrm{FSW}, \mathrm{NO}_{2}^{-}$(final concentration, $2 \mu \mathrm{M}$ ) and approximately $1 \times 10^{6}$ cells $\mathrm{ml}^{-1}$ of actively growing nitrite oxidizing bacteria. Three duplicate sets were used. The control set received a $1 \mathrm{ml}$ dose from the dark cuvette and remained wrapped in foil during the rest of the incubation. The other 2 sets received $1 \mathrm{ml}$ samples from the irradiated cuvette. All serum bottles were allowed to incubate on a rotatory shaker at $150 \mathrm{rpm}$ at $25^{\circ} \mathrm{C}$ for $4 \mathrm{~h}$.

In addition, absorbance scans of cuvette contents were run before and after irradiations. A new peak or shift from original absorption maxima was taken as an indication of an additional product being formed during illumination.

Dose rate: To test for reciprocity (dose $\times$ time), light fluences of 20 to 25 and 10 to $12 \mathrm{~W} \mathrm{~m}^{-2}$ were used for 2 and 4 h, respectively.

Analytical methods. Nitrifying activity was assayed by $\mathrm{NO}_{2}^{-}$determinations using the spectrophotometric method of Bendschneider \& Robinson (1952). Nitrite production was used as an index of ammonium oxidation, and nitrite disappearance as an indication of nitrite oxidation.

Replicate samples were run for each experiment. Samples were collected in duplicates, and the data points correspond to the mean of the duplicates. Correlation analyses $\left(r^{2}\right)$ and Student's $t$-tests were used to determine relationships between 2 variables and statistical significance, respectively.

\section{RESULTS}

In order to choose appropriate conditions for action spectroscopy (photoresponse vs $\lambda$ ), it was necessary to first determine a time course of photoinactivation for $\mathrm{NH}_{4}{ }^{+}$and $\mathrm{NO}_{2}{ }^{-}$oxidation (Fig. 1). The 2 types of nitri-

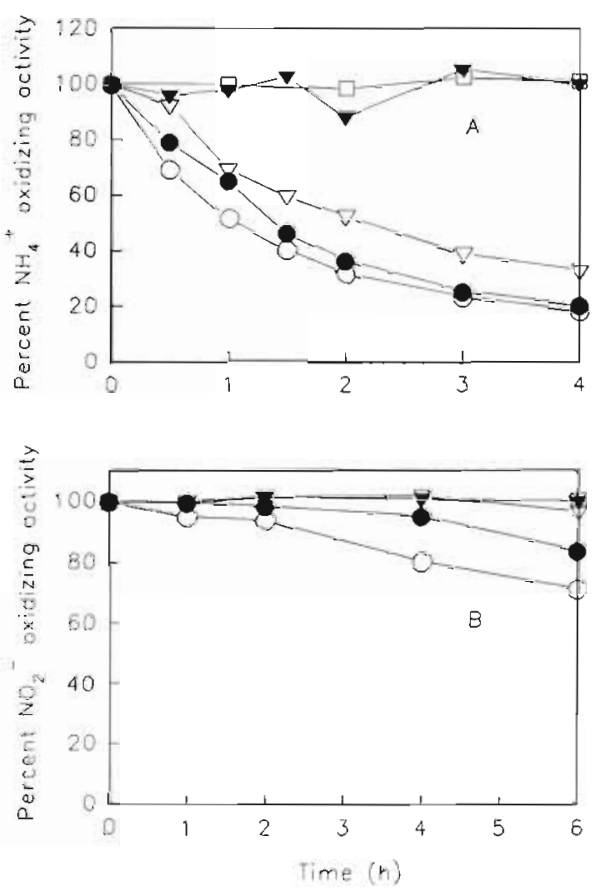

Fig. 1 Time course of photoinactivation. (A) Nitrosomonas cryotolerans after a total irradiation period of $4 \mathrm{~h}$ with $10 \mu \mathrm{M}$ $\mathrm{NH}_{4}{ }^{+}$(B) Nitrobacter sp. (25W30N) after $6 \mathrm{~h}$ with $2 \mu \mathrm{M} \mathrm{NO}_{2}{ }^{-}$ Activities are expressed at $1 \times 10^{6}$ cells $\mathrm{ml}^{-1}$ Light intensity was $25 \mathrm{~W} \mathrm{~m}^{-2}$ (0) $300 \mathrm{~nm}$; (•) $400 \mathrm{~nm}$; (V) $475 \mathrm{~nm}$;

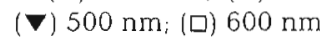


fying bacteria $\left(\mathrm{NH}_{4}{ }^{+}\right.$and $\mathrm{NO}_{2}{ }^{-}$oxidizers) exhibited different rates of photoinactivation. For instance, Nitrosomonas cryotolerans exhibited a noticeable decrease in activity, showing a 20 to $30 \%$ loss of activity after only 30 min of light exposure (Fig. 1A). Light sensitivity was more marked at the lower end of the spectrum (300 to $400 \mathrm{~nm}$ ), though longer wavelengths were still effective during relatively short periods of exposure (e.g $30 \%$ inhibition after $1 \mathrm{~h}$ of $475 \mathrm{~nm}$ irradiation). In contrast, Nitrobacter sp. required longer periods of illumination to show decreased activity (Fig 1B). A significant reduction in the rates of nitrite oxidation $(\mathrm{p}<$ 0.05 ) was observed only after a minimum of $4 \mathrm{~h}$ of irradiation with the shorter wavelengths ( 300 to $375 \mathrm{~nm}$ ).

The increase of ammonium oxidation rates when substrate concentration was raised (from 10 to $100 \mu \mathrm{M}$ $\mathrm{NH}_{4}{ }^{+}$) enhanced light tolerance in ammonium oxidizers (Fig. 2A, B). For Nitrosomonas cryotolerans, an otherwise $60 \%$ inhibitjon $(450 \mathrm{~nm}$; Fig. 2A) could be reduced by more than half $(450 \mathrm{~nm}$; Fig. $2 \mathrm{~B})$ when $\mathrm{NH}_{4}{ }^{+}$concentration was increased. The same substrate photoprotection was not observed with Nitrococcus mobilis which did not significantly alter their light response $(p>0.05$; Fig. $2 C, D)$, regardless of the substrate concentration employed ( 2 or $5 \mu \mathrm{M} \mathrm{NO}_{2}^{-}$). In the case of ammonium oxidizers, the only instance in which substrate protection did not apply was with the shortest wavelength tested (300 nm; Fig. 2B).

The total number of bacteria present could influence the light response among nitrifying bacteria differently. Light sensitivity by Nitrosomonas cryotolerans was not altered significantly $(p>0.05)$ when the number of cells in the suspension was increased from $10^{4}$ to $10^{6}$ cells $\mathrm{ml}^{-1}$ (Fig, 2E, F). At most, a change from 1.2 to $28 \%$ activity was detected when using cell concentrations of $10^{4}$ and $10^{6}$ cells $\mathrm{ml}^{-1}$ (Fig. $2 \mathrm{~F}$ ), respectively.

In contrast, the nitrite oxidizer Nitrobacter sp. exhibited a statistically significant $(p<0.05)$ light sensitivity at higher cell densities (Fig. 2G, H). Light with a wavelength of $425 \mathrm{~nm}$ that did not have an inhibitory effect became inhibitory whenever cell densities above $10^{6}$ cells $\mathrm{ml}^{-1}$ were used (data not shown). Ammonium oxidizers did not exhibit the same behavior.

By adding conditioned medium $(1 \mathrm{ml})$ from irradiated cultures to actively growing cultures of nitrite oxidizers it was possible to test for a cell product capable of inhibiting nitrite oxidizing activity, as summarized in Table 1 Cultures added with the conditioned media started accumulating nitrite, denoting decreased nitrite oxidation. In addition, if the irradiated sample was previously filtered $(0.2 \mu \mathrm{m})$ the effect was not as evident. Absorbance scans of the light cuvette contents run before and after irradiations did not show a noticeable change. A shift in difference maxima would have been taken as an indication of a new product.

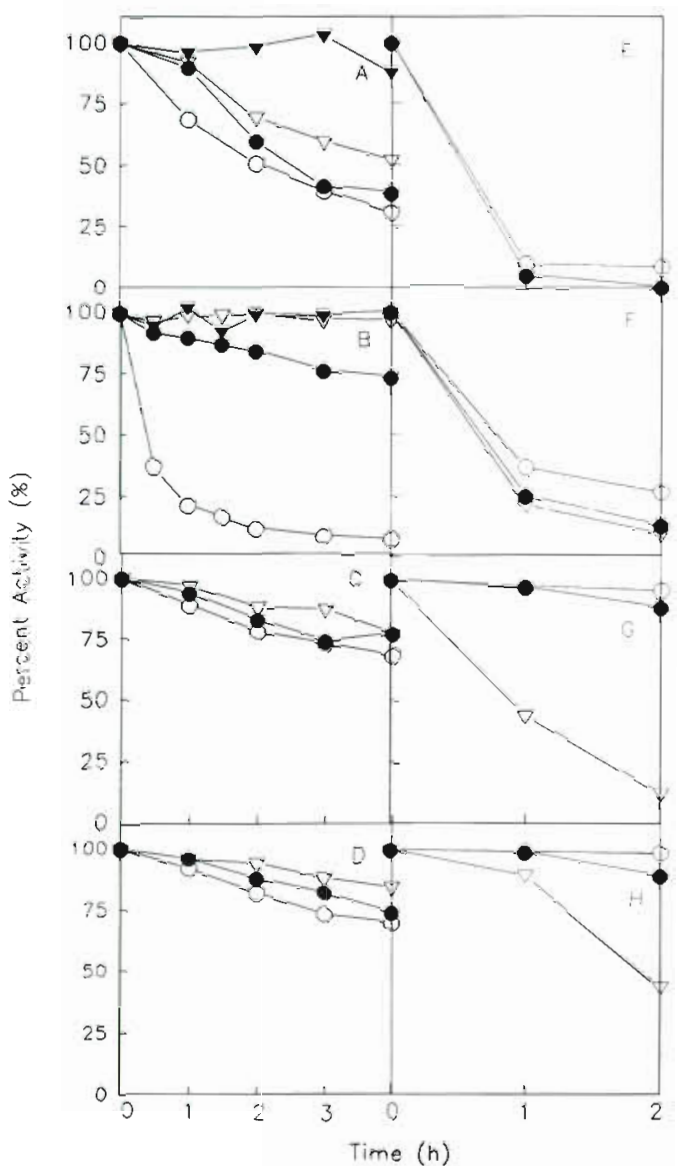

Fig. 2. Effect of substrate concentration and cell density on photoinactivation by different wavelengths of light. Substrate concentration: Nitrosomonas cryotolerans: (A) $10 \mu \mathrm{M}$ $\mathrm{NH}_{4}{ }^{+}$, (B) $100 \mu \mathrm{M} \mathrm{NH}_{4}{ }^{+}$; (O) $300 \mathrm{~nm},(\bullet 450 \mathrm{~nm},(\nabla) 475 \mathrm{~nm}$, (V) $500 \mathrm{~nm}$. Nitrococcus mobilis: (C) $2 \mu \mathrm{M} \mathrm{NO}{ }_{2}^{-}$, (D) $5 \mu \mathrm{M}$ $\mathrm{NO}_{2}^{-}$; (O) $300 \mathrm{~nm},(\bullet) 350 \mathrm{~nm},(\nabla) 400 \mathrm{~nm}$. N. cryotolerans with $100 \mu \mathrm{M} \mathrm{NH}_{4}{ }^{+}$: (E) $300 \mathrm{~nm}$, (F) $450 \mathrm{~nm}_{\text {i cell densities }}$ were (O) $1 \times 10^{4}$ cells ml-1, (๑) $1 \times 10^{5}$ cells ml ${ }^{-1},(\nabla) 1 \times 10^{6}$ cells $\mathrm{ml}^{-1} \mathrm{~N}$. mobilis with $2 \mu \mathrm{M} \mathrm{NO}_{2}^{-}$: (G) $325 \mathrm{~nm}$, (H) 375

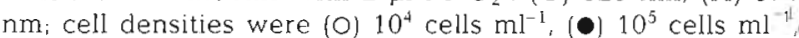
$(\nabla) 10^{6}$ cells $\mathrm{ml}^{-1}$. Activities are expressed at $1 \times 10^{6}$ cells $\mathrm{ml}^{-1}$. Light intensity was $25 \mathrm{~W} \mathrm{~m}^{-2}$

Table 1. Nitrite accumulation by actively growing Nitrobacter spp. in the presence of conditioned media (conditioned or spent medium was obtained after cells' activity took place for a period of 3 to $4 \mathrm{~h}$ )

\begin{tabular}{|cccc|}
\hline $\begin{array}{c}\text { Time } \\
(\mathrm{h})\end{array}$ & Control & $\begin{array}{c}{\left[\mathrm{NO}_{2}-\mu \mathrm{M}\right.} \\
0.2 \mu \mathrm{m} \text { filtered }\end{array}$ & Unfiltered \\
\hline 0 & $1.44(100 \%)$ & $1.44(100 \%)$ & $1.44(100 \%)$ \\
1 & $1.19(83 \%)$ & $1.34(93 \%)$ & $1.31(91 \%)$ \\
2 & $0.98(68 \%)$ & $1.23(85 \%)$ & $1.15(80 \%)$ \\
3 & $0.86(60 \%)$ & $1.23(85 \%)$ & $1.02(71 \%)$ \\
4 & $0.65(45 \%)$ & $1.12(78 \%)$ & $0.82(57 \%)$ \\
5 & $0.57(40 \%)$ & $1.12(78 \%)$ & $0.78(54 \%)$ \\
\hline
\end{tabular}


Photoinhibition was found to depend not only upon the quality but also the quantity of light. Light intensities as low as $15 \mathrm{~W} \mathrm{~m}^{-2}$ could cause a 50 to $70 \%$ inhibition of $\mathrm{NH}_{4}{ }^{+}$oxidizing activity after a $2 \mathrm{~h}$ exposure $(p<0.05$; Table 2). Higher doses (25 $\left.\mathrm{W} \mathrm{m}^{-2}\right)$ did not change the end result noticeably. It should be noted that the dose-dependent response was more dramatic at the shorter wavelengths (300 to $400 \mathrm{~nm}$ ). The longer wavelength tested $(500 \mathrm{~nm})$ remained ineffective even at the highest dose used $\left(25 \mathrm{~W} \mathrm{~m}^{-2}\right)$. Nitrite oxidizers showed negligible photoinactivation when subjected to monochromatic irradiations at a dose of $25 \mathrm{~W} \mathrm{~m}^{-2}$ (Table 2). Only near-UV light in conjunction with high cell densities (Fig. 2G, H) resulted in some photoinactivation.

The efficiency of photoinactivation changes, depending on the dose and rate of exposure. To test for reciprocity (dose $\times$ time), light fluences of 20 to 25 and 10 to $12 \mathrm{~W}$ $\mathrm{m}^{-2}$ were used for 2 and $4 \mathrm{~h}$, respectively. Nitrosomonas cryotolerans results (Fig. 3 ) are shown as representative of the ammonium oxidizer response. Highest light sensitivities appear at the shorter wavelengths (300 to $400 \mathrm{~nm}$ ), but the extent of light inhibition is reduced at all wavelengths in general (300 to $475 \mathrm{~nm}$ ) whenever the lower dose $\left(10 \mathrm{~W} \mathrm{~m}^{-2}\right)$ and the longest time of exposure $(4 \mathrm{~h})$ were used.

Nitrite oxidizers showed the opposite response (Fig. 3B). The lower dose $\left(12 \mathrm{~W} \mathrm{~m}^{-2}\right)$ along with the longer time of exposure ( $4 \mathrm{~h}$ ) increased their light sensitivity $(\mathrm{p}<0.05)$. The apparent lack of trend observed (lower dose = higher inhibition) is a result of the difficulty of using the same number of cells from experiment to experiment, and, as discussed above, cell density variation can alter significantly the expected phototolerance of nitrite oxidizers.

\section{Monochromatic illumination: wavelength-dependent response}

Action spectral analyses were conducted to determine the wavelength limits of the radiation causing photoinhibition. $\mathrm{NH}_{4}{ }^{+}$oxidizing activity was drastically decreased at the shorter wavelengths (300 to $375 \mathrm{~nm}$ ). The activities recorded for Nitrosomonas cryotolerans as well as for Nitrosococcus oceanus at these wavelengths did not exceed $15 \%$. For $N$. cryotolerans there was a gradual loss of light sensitivity (i.e. $55 \%$ inhibition at $450 \mathrm{~nm}, 32 \%$ inhibition at $475 \mathrm{~nm}$, etc.) at the cells $\mathrm{ml}^{-1}$
Table 2. Influence of light intensity on nitrifying activity

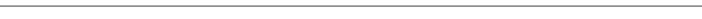

\begin{tabular}{ccccc}
$\mathrm{Nm}^{-2}$ & \multicolumn{4}{c}{ Percent activity $(\%)$} \\
$\begin{array}{c}\mathrm{N} \text {. cryo- } \\
\text { tolerans }\end{array}$ & $\mathrm{N}$. & Nitro- & $\mathrm{N}$ \\
oceanus & bacler sp. & mobilis \\
\hline
\end{tabular}

$\begin{array}{lllll}400 & 1.2 & 6.25 & 83 & 33\end{array}$

Monochromatic

$5 \quad 30.8$

$15 \quad 31.47$

$25 \quad 22.1$

$\begin{array}{llll}350 \mathrm{~nm} & 5 & 64.86 & 98.8\end{array}$

$\begin{array}{lr}32.89 & 100 \\ 32 & 97.5\end{array}$

$25 \quad 32$

79.2

34.61

47.12

87.91

52.11

39.28

96.58

88.59

99.71

Irradiation time was $2 \mathrm{~h}$. Activities are expressed at $1 \times 10^{6} \mathrm{cells} \mathrm{ml}^{-1}$ . cryotolerans was irradiated for $2 \mathrm{~h}$ with $10 \mu \mathrm{M} \mathrm{NH}_{4}{ }^{*}$. Nitrobacter $\mathrm{sp}$. was irradiated for $4 \mathrm{~h}$ with $2 \mu \mathrm{M} \mathrm{NO}_{2}{ }^{-}$Activities are expressed at $1 \times 10^{6}$

longer wavelengths (400 to $475 \mathrm{~nm}$ ). For $N$. oceanus there was a steady light inhibition up to $475 \mathrm{~nm}(80 \%$ inhibition) and a sharp drop in photosensitivity above $475 \mathrm{~nm}$ (Fig. 4A).

Overall $\mathrm{NO}_{2}{ }^{-}$oxidizing activity showed a remarkable phototolerance when compared to $\mathrm{NH}_{4}^{+}$oxidizing
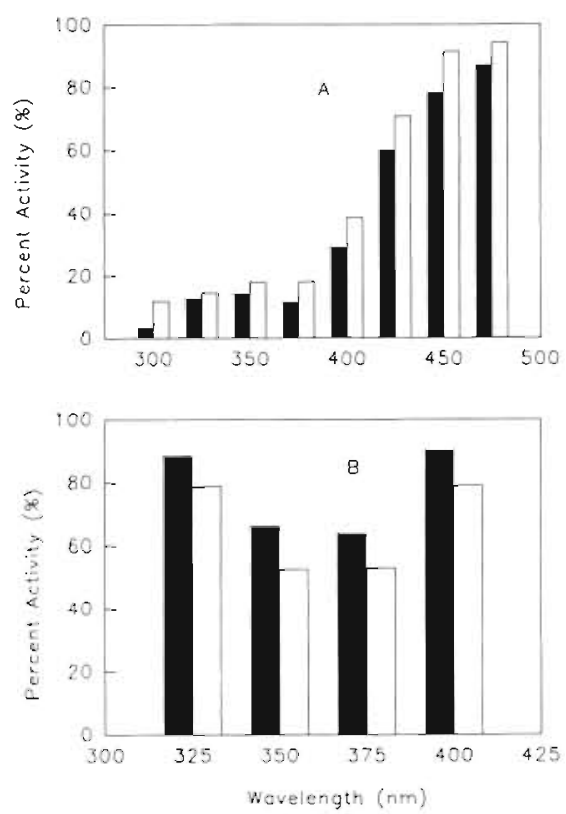

Fig. 3. Dose rate relationships: (A) Nitrosomonas cryotolerans, with $100 \mu \mathrm{M} \mathrm{NH}_{4}{ }^{+}$; (B) Nitrococcus mobilis, with $2 \mu \mathrm{M} \mathrm{NO}_{2}$ Wavelengths used were from 300 to $475 \mathrm{~nm}$ in $25 \mathrm{~nm}$ increments. Activities are expressed at $1 \times 10^{6}$ cells $\mathrm{ml}^{-1}$ Solid bars:

$2 \mathrm{~h}$ at 20 to $25 \mathrm{~W} \mathrm{~m}^{-2}$; open bars: $4 \mathrm{~h}$ at 10 to $12 \mathrm{~W} \mathrm{~m}^{-2}$ 

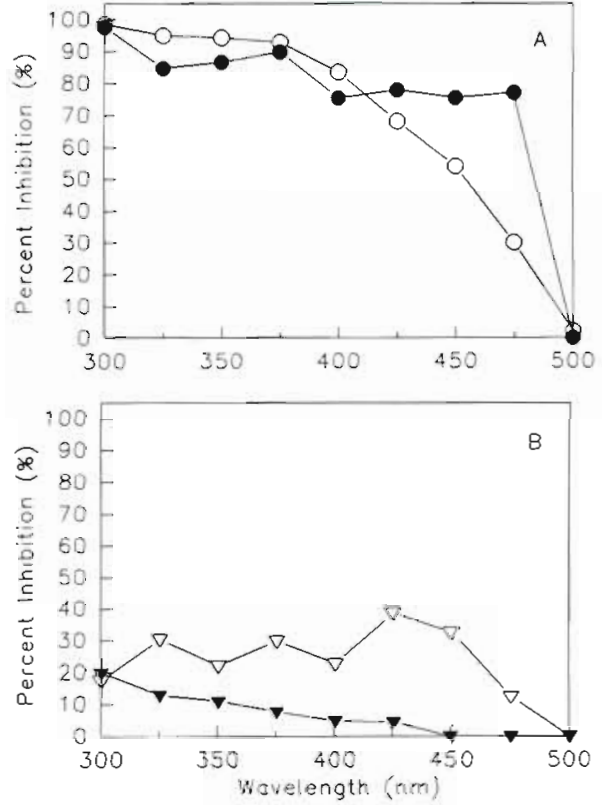

Fig. 4. Action spectra. (A) Ammonium oxidizing activity with $100 \mu \mathrm{M} \mathrm{NH}_{4}{ }^{+}$Irradiation time was $2 \mathrm{~h}$. (B) Nitrite oxidizing activity with $2 \mu \mathrm{M} \mathrm{NO}_{2}{ }^{-}$Irradiation time was $4 \mathrm{~h}$. Light intensity was $25 \mathrm{~W} \mathrm{~m}^{-2}$ Activities are expressed at $1 \times 10^{6}$ cells ml $^{-1}$ (O) Nitrosomonas cryotolerans; (•) Nitrosococcus oceanus; $(\nabla)$ Nitrococcus mobilis; ( $\nabla)$ Nitrobactersp. (25W30N)

activity. The slight photoinactivation experienced by nitrite oxidizers (ca 15\%) was limited to the shorter wavelengths (300 to $450 \mathrm{~nm}$; Fig. 4B). Comparatively, Nitrococcus mobilis exhibited more photoinhibition (20 to $40 \%$ ) and the same pattern as $\mathrm{NH}_{4}{ }^{+}$oxidizers: the shorter the wavelength, the greater the light inhibition. Yet, the reduction of $\mathrm{NO}_{2}^{-}$oxidizing activity $(<40 \%$; Fig. $4 \mathrm{~B})$ is still significantly lower $(\mathrm{p}<0.05)$ than the decrease in $\mathrm{NH}_{4}{ }^{+}$oxidizing activity (<90\%; Fig. $4 \mathrm{~A}$ ).

\section{Effect of polychromatic illumination}

\section{Cool-white fluorescent light}

Because nitrite oxidizers were found to be insensitive to this type of light (Vanzella et al. 1989), only ammonium oxidizers were tested in this respect. Both ammonium oxidizers were examined by inflicting fluorescent illumination on the chemostat bottles in which they were growing. Illumination periods were of 8 or $12 \mathrm{~h}$ followed by 16 or $12 \mathrm{~h}$ dark periods, respectively. Both illumination treatments gave an immediate response. For instance, by sampling at hourly intervals, it was observed that within the first hour the $\mathrm{pH}$ in the chemostat increased, while the nitrite concentration dropped (Table 3). With the 8:16 h light:dark chemostat, $\mathrm{pH}$ increased from 7.85 to
Table 3. Effect of periodıc illumination on Nitrosomonas cryotolerans (chemostat)

\begin{tabular}{|ccccc|}
\hline $\begin{array}{c}\text { Time } \\
\text { (h) }\end{array}$ & \multicolumn{3}{c}{$8: 16$ h light:dark } & \multicolumn{2}{l}{$12: 12$ h light:dark } \\
& $\mathrm{pH}$ & $\mathrm{NO}_{2}^{-}, \mu \mathrm{M}$ & $\mathrm{pH}$ & $\mathrm{NO}_{2}^{-}, \mu \mathrm{M}$ \\
\hline 1 & 7.85 & 4.46 & 7.84 & 4.5 \\
2 & 7.93 & 3.76 & 7.86 & 4.37 \\
3 & 8.04 & 3.51 & 7.94 & 3.5 \\
4 & 8.12 & 3.76 & 8.06 & 3.3 \\
5 & 8.14 & 2.71 & 8.13 & 2.8 \\
6 & 8.17 & 2.99 & 8.22 & 2.7 \\
7 & 8.24 & 2.80 & 8.23 & 2.1 \\
8 & 8.27 & 1.46 & 8.25 & 1.7 \\
9 & & & 8.27 & 1.0 \\
10 & & & 8.30 & 0.7 \\
11 & & & 8.35 & 0.5 \\
12 & & & 8.35 & 0.58 \\
\hline
\end{tabular}

8.3, while nitrite decreased from 4.5 to $1.5 \mu \mathrm{M}$, denoting the decrease in activity experienced upon fluorescent illumination.

\section{Sunlight}

The monochromatic and fluorescent light sources used in this study show considerable qualitative and quantitative differences in their spectra as compared to sunlight. No attempt was made to filter sunlight or to decrease light intensity. Instead, the light dose received by all the species tested was kept almost uniform, such that the integrated light fluence was within the 360 to $400 \mathrm{~W} \mathrm{~m}^{-2}$ range. An almost complete inhibition was detected within the first $30 \mathrm{~min}$, in the case of ammonium oxidizers ( $20 \%$ remaining activity). Both Nitrosomonas cryotolerans and Nitrosococcus oceanus lost up to $90 \%$ of their $\mathrm{NH}_{4}{ }^{+}$oxidizing activity after $2 \mathrm{~h}$ of sunlight exposure (Table 2). Nitrite oxidizers appeared somewhat sunlight-resistant, because their activities did not decrease to the extent of those of ammonium oxidizers. Thus, sunlight experiments served to verify the observed near-UV sensitivity common to both types of nitrifiers.

\section{DISCUSSION}

This study confirmed the fact that marine ammonium and nitrite oxidizers can be photoinactivated, yet it differs from the previous reports in as much as which microorganisms were more light-sensitive. The use of natural populations as opposed to pure cultures, the species employed, and the light sources and intensities used can help to explain the difference in results with previous investigations. In earlier studies with either soil (Müller-Neuglück \& Engel 1961, Schön \& Engel 
1962) or aquatic nitrifiers (Olson 1981, Yoshioka \& Saijo 1984, Diab \& Shilo 1988), $\mathrm{NO}_{2}$ - oxidizers were described as more light-sensitive than $\mathrm{NH}_{4}{ }^{+}$oxidizers. In this case, and at the various wavelengths tested $(300$ through $500 \mathrm{~nm}$ ), both of the $\mathrm{NH}_{4}{ }^{+}$oxidizers tested (Nitrosomonas cryotolerans and Nitrosococcus oceanus) exhibited a greater light sensitivity than the nitrite oxidizers (Nitrococcus mobilis and Nitrobacter sp.). These types of results agree with the previous work of Vanzella et al. (1989)

Each species varied in their individual light responses (Fig 4A, B); for instance, Nitrococcus mobilis was more light-sensitive than Nitrobacter $\mathrm{sp}$, and among the ammonium oxidizers, Nitrosococcus oceanus was more photosensitive than Nitrosomonas cryotolerans. Strain variability is recognized in instances such as substrate and product inhibition (Boon \& Laudelot 1962, Focht \& Verstraete 1977), effect of nitrification inhibitors (Belser \& Schmidt 1981, Jones \& Morita 1984), resistance to high oxygen concentrations (Gunderson 1966), etc. Thus, it is not surprising that light response can vary markedly between different species and different genera. Natural ecosystems show a coexistence of different species of nitrifying bacteria (Fliermans et al. 1974, Belser \& Schmidt 1978a, b) that will more than likely exhibit different degrees of photosensitivity, but whether this is significant in natural environments remains to be assessed.

Action spectroscopy revealed a widespread photosensitivity in the near-UV (300 to $375 \mathrm{~nm}$ ) region for nitrifying bacteria. Nevertheless, the relative phototolerance of nitrite oxidizers was evidenced even at these relatively short wavelengths. Important naturally occurring chromophores in this region of the spectrum may be either 4 -thiouridine, pyridoxine compounds, nicotinamide adenine dinucleotide (NADH), or electron transport molecules. 4-thiouridine $\left({ }^{4} \mathrm{Srd}\right)$ is an unusual DNA base which can extend the high far-UV absorption of transfer RNA into the near-UV region, with a peak at $340 \mathrm{~nm}$ provoking a variety of sublethal biological effects (Jagger 1983). Pyridoxine compounds act as prosthetic groups or coenzymes, and show strong absorption throughout the near-UV region, with peaks at 325 and $388 \mathrm{~nm}$ (Jagger 1981). NADH in its reduced form absorbs light best at $340 \mathrm{~nm}$ (Jagger 1981). Quinones and flavins are among the suggested candidate electron transport molecules (Epel 1973). The inhibition continuum observed in the near-UV region could be the result of absorption by any of the above or of the summation of the individual absorption properties of the above. The relevance of near-UV impacting marine environments is limited to the surface of oceans; therefore, the complete elucidation of the phototarget in the near-UV region was not pursued.
The visible region examined in this work (400 to $500 \mathrm{~nm}$ ) was where most of the differential photosensitivity among nitrifiers was exhibited. This type of light did not disturb nitrite oxidizing activity considerably (ca <15\%; Fig 4B); yet, photoinhibition of up to $80 \%$ was detected for ammonium oxidizing activity (Fig. 4A). Action spectra of intact organisms constitute a good start for the evaluation of biological responsiveness to monochromatic (i.e. narrowband) irradiation. Yet, it can be argued that the effect of polychromatic (i.e. broadband) irradiation is of more ecological relevance. Broadband irradiation more closely approximates the total influence, both beneficial and detrimental, of all wavelengths present in natural sunlight. The similarities (intensities) and differences (wavebands) of the various types of light (monochromatic, polychromatic) can be considered an advantage, since results can be compared and contrasted. For instance, the blue sensitivity of ammonium oxidizers was corroborated when broadband irradiations were performed using cool-white fluorescent light. Similarly, nitrite oxidizers were confirmed as blue light insensitive, since fluorescent illumination did not affect them. The photosensitivity of both types of nitrifying bacteria to near-UV light was corroborated when these organisms were subjected to sunlight irradiations.

In this work nitrifying bacteria also showed opposing responses to other factors besides light. One of the factors studied was that of substrate protection. $\mathrm{NH}_{4}{ }^{+}$oxidizers became less photosensitive in the presence of higher $\mathrm{NH}_{4}{ }^{+}$concentrations, while $\mathrm{NO}_{2}{ }^{-}$oxidizers did not significantly change their light response if nitrite concentration was increased.

At substrate concentrations of 2 and $100 \mu \mathrm{M}$ for $\mathrm{NO}_{2}{ }^{-}$and $\mathrm{NH}_{4}{ }^{+}$, respectively, it is expected that both nitrite and ammonium can enter the cells by passive diffusion. However, ammonium oxidizers in marine environments experience only submicromolar concentrations of $\mathrm{NH}_{4}{ }^{+}$and may survive in this habitat due to the highly efficient enzyme systems and adaptations that pelagic marine bacteria possess (Azam \& Hodson 1981, Jones \& Morita 1985). At this point, there are at least 3 possibilities: it can be argued that such highly specialized marine bacteria may have lost their low substrate affinity by maintenance in pure culture; that the detrimental effects of light affect $\mathrm{NH}_{4}{ }^{+}$transport mechanisms, if any; or that rapidly growing cells (i.e. high nitrification rates) better tolerate the constraints that light imposes on them. Assuming that repairing photoimpact is an energy-dependent process, those cells with higher nitrification rates would more efficiently cope with the damage caused by light. Perhaps, at low substrate concentrations, one or a combination of the abovementioned factors could have intervened on the activity measurements and made it 
appear as if excess substrate had a photoprotective effect.

Nitrite oxidizers are considered versatile in many respects. They are known for their heterotrophy (Bock 1976), mixotrophy (Smith \& Hoare 1968), heterogeneity among species (Navarro et al. 1992), anaerobic growth by dissimilatory nitrate reduction (Freitag et al. 1987, Bock et al. 1988, Freitag \& Bock 1990), as well as alternate respiratory chains (Bock et al. 1986, Nomoto et al. 1993). The inherent metabolic diversity of nitrite oxidizers may be the key to their phototolerance. For instance, if light affected 1 electron mediator in the electron transport system (ETS), there is the possibility that nitrite oxidizers could switch to an alternate respiratory component and therefore withstand illumination at lower substrate concentrations much better than could their counterpart (ammonium oxidizers). More work concerning regulation and control of substrate oxidation could clarify this matter.

Cell density is another factor that can modify light response by nitrifying bacteria. At higher cell densities there was a considerable decrease in activity for nitrite oxidizers $(p<0.05)$, but not for ammonium oxidizers. The contrasting results $\left(\mathrm{NH}_{4}{ }^{4}\right.$ oxidizers vs $\mathrm{NO}_{2}^{-}$oxidizers) were not the product of $\mathrm{pH}$ shifts. The nature of these short-term ( 2 to $4 \mathrm{~h}$ ) activity measurements did not allow for a change in $\mathrm{pH}$, outside the effective $\mathrm{pH}$ range for autotrophic nitrification $(\mathrm{pH} 7$ to 8). A maximum drop of $0.3 \mathrm{pH}$ units was measured at the end of the incubation period, when cell densities of $10^{6}$ cells $\mathrm{ml}^{-1}$ were used. $\mathrm{O}_{2}$ limitation was also not considered to be significant. Although the $K_{\mathrm{m}}$ for oxygen consumption is high among nitrifying bacteria 10.3 to $1.0 \mathrm{mg} \mathrm{O}_{2} \mathrm{ml}^{-1}$; Boon \& Laudelot 1962, Loveless \& Painter 1968), $\mathrm{O}_{2}$ was not limiting as evidenced by nitrite oxidation rates observed in controls.

A simple cell product test showed a relationship between adding conditioned media and greater photosensitivity by nitrite oxidizers. If it were only an end product causing the loss of nitrite oxidation, it is expected that cultures taken from both dark as well as irradiated cell suspensions would (at the same cell density) cause the same decrease in activity, but this was not the case. Thus, there is either an 'additional' product that is produced by the irradiated cells, or more of the end product is made under continuous illumination. The nature of the cell product was not investigated. Boon \& Laudelot (1962) found a non-competitive product inhibition effected by nitrate, which at this point can be taken as a plausible explanation. In addition to the accumulation of nitrate as an end product, there is the potential for concurrent photochemical formation of nitrate (Zafiriou \& True 1979) with the shortest wavelength used. These findings may also explain previous reports (Müller-Neuglück \& Engel 1961, Bock 1965, Olson 1981, Yoshioka \& Saijo 1984, Diab \& Shilo 1988) where cell densities were not considered an important variable and resulted in an increased photosensitivity of nitrite oxidizers as compared to ammonium oxidizers.

Photoinhibition depended on both the quality and the quantity of light. In this work, emphasis was placed on the action of wavelengths in the near-UV (300 to $400 \mathrm{~nm})$ to the visible $(400$ to $500 \mathrm{~nm}$ ) region, and not in far-UV (190 to $280 \mathrm{~nm}$ ) since all cell types are susceptible to far-UV, and microorganisms under natural conditions are not subjected to these shorter wavelengths. A dose-dependent response was observed that demanded higher fluences to achieve the same photoinactivation at the longer wavelengths. This can be easily explained in terms of differential targets for the various types of light. For instance, farUV can alter proteins and nucleic acids, which do not absorb significantly at longer wavelengths (i.e. 300 to $500 \mathrm{~nm}$. Considering the vital role of DNA and proteins, it is expected that at longer wavelengths (>300 nm) the fluences required to produce biological effects, other than mutation and killing, will be much higher (Eisenstark 1971, Epel 1973, Jagger 1983).

Another critical condition that concerns photoprocesses is the biological dose to affect them; the dose being the product of irradiance and the length of exposure time. It was determined that reciprocity of time and dose did not apply in any of the cases, with either ammonium or nitrite oxidizers. Yet, even in this aspect both types of nitrifiers also differed. In the case of ammonium oxidizers, the short-time/high-intensity ( $2 \mathrm{~h}$ at 20 to $25 \mathrm{~W} \mathrm{~m}^{-2}$ ) experiments showed a more drastic photoinactivation than those with long-time/ low-intensity ( $4 \mathrm{~h}$ at 10 to $12 \mathrm{~W} \mathrm{~m}^{-2}$ ). Presumably, as far as ammonium oxidizers are concerned, the lack of reciprocity may involve the time rates and spectral responses of their repair mechanisms in relation to the time rates and phototargets of the damaging radiation.

Nitrite oxidizers do not exhibit the same behavior: long-time/low-intensity exposure had a greater photoeffect than the short-time/high-intensity exposure. Another incongruity was that longer wavelengths were sometimes more effective than shorter ones (Fig. 3B). Part of the inconsistency of these results may have arisen from the use of different cell batches; the inability to keep the exact same number of cells from experiment to experiment, and the abovementioned cells' product inhibition. That longer exposure times favor photoinactivation represents a good line of evidence for the cell product argument, since its concentration increases with time.

There is ample laboratory evidence concerning photoinhibition of nitrification. However, the ability to 
accurately and unambiguously predict light consequences in aquatic (freshwater/marine) habitats remains elusive. Difficulties in quantitatively extrapolating laboratory findings to natural populations include the complexity of the spectral characteristics of water and/or water movements, and the possibility that natural communities might adapt through selection of resistant types. For instance, Horrigan \& Springer (1990) reported reduced sensitivity to light by ammonium oxidizers from shallow estuarine environments as compared to marine isolates. What cannot be distinguished from their data is whether the estuarine bacteria are intrinsically less sensitive to light than marine bacteria, or if higher nitrification rates were favored by the increased turbidity (i.e. decreased light penetration) this habitat may offer.

In any event, the assorted light responses described in this work suggest that when studying nitrification in a particular environment, it would be ideal to determine nitrification activity and diversity. That nitrification in nature proceeds under a range of conditions, even those intolerable for pure cultures, may be an indication of how the adaptive capabilities of nitrifying bacteria may be underestimated. These data indicate that photoeffect on nitrification can be modified if 1 or more of the variables cited above were changed. More work dealing with the different sensitivities of $\mathrm{NH}_{4}{ }^{+}$ and $\mathrm{NO}_{2}{ }^{+}$oxidation would give more insight into the interrelationships of both groups and the consequences to the overall process.

Acknowledgements. This work was supported by the National Science Foundation under grants OCE-8922815 and OCE-9416560. This is Southeast Environmental Research Program Contribution Number 35.

\section{LITERATURE CITED}

Azam F, Hodson RE (1981) Multiphasic kinetics for D-glucose uptake by assemblages of natural marine bacteria. Mar Ecol 6:213-222

Belser LW, Schmidt EL (1978a) Diversity in the ammonıoxidizing population of a soil. Appl Environ Microbiol 36: $584-586$

Belser LW, Schmidt EL (1978b) Serological diversity within a terrestrial ammonia-oxidizing population. Appl Environ Microbiol 36:589-593

Belser LW, Schmidt EL (1981) Inhibitory effect of nitrapyrin on three genera of ammonia-oxidizing nitrifiers. Appl Environ Microbiol 41:819-821

Bendschneider K, Robinson RJ (1952) A new spectrophotometric method for the determination of nitrite in sea water. J Mar Res 11:87-96

Bock E (1965) Vergleichende Untersuchungen über die Wirkung sichtbaren Lichtes auf Nitrosomonas europaea und Nitrobacter winogradskyi. Arch Mikrobiol 51:18-41

Bock E (1976) Growth of Nitrobacter in the presence of organic matter. II. Chemoorganotrophic growth of Nitro- bacter agilis. Arch Microbiol 108:305-312

Bock E, Koops H, Harms H (1986) Nitrification. IRL Press, Washington, DC

Bock E, Wilderer PA, Freitag A (1988) Growth of Nitrobacter in the absence of dissolved oxygen. Wat Res 22:245-250

Boon B, Laudelot $H$ (1962) Kinetics of nutrite oxidation by Nitrobacter winogradskyi. Biochem J 85:440-447

Craıg RE (1973) Marune physics. Academic Press, Inc., London

Diab S, Shilo M (1988) Effect of light on the activity and survival of Nitrosomonas sp. and Nitrobacter sp. isolates from fish ponds. Bamidgeh 40:50-56

Eisenstark A (1971) Mutagenic and lethal effects of visible and near-ultraviolet light on bactenal cells. Adv Genet 16: $167-198$

Epel BL (1973) Inhibition of growth and respiration by visible and near-visible light. In: Giese AC (ed) Photophysiology. Academic Press, New York, p 209-229

Fliermans CB, Bohlool BB, Schmidt EL (1974) Autoecological study of the chemoautotroph Nitrobacter by immunofluorescence. Appl Microbiol 27:124-129

Focht DD, Verstraete W (1977) Biochemical ecology of nitrification and denitrification. Adv Microbiol Ecol 1: $135-214$

Freitag A, Bock E (1990) Energy conservation in Nitrobacter. FEMS Microbiol Lett 66:157-162

Freitag A, Rudert M, Bock E (1987) Growth of Nitrobacter by dissimilatoric nitrate reduction. FEMS Microbiol Lett 48 : $105-109$

Gieskes WW, Heusel R, Kraay G, Tilzer MM (1989) The underwater light climate. In: Hempel I (ed) The expedition Antarktis VIL/1 and 2 (EPOS I) of RV 'Polarstern' in 1988/1989. Alfred-Wegener-Institut für Polar- und Meeresforschung, Bremerhaven, p 75-83

Gunderson K (1966) The growth and respiration of Nitrosocystis at differential partial pressures of oxygen. J Gen Microbiol 42:387-396

Hatchard CG, Parker CA (1956) A new sensitive chemical actinometer. II. Potassium ferrioxalate as a standard chemical actinometer. Proc R Soc Lond Ser A 235:518-536

Horrigan SG, Springer AL (1990) Oceanic and estuarine ammonium oxidation: effects of light. Limnol Oceanogr 35:479-482

Jagger J (1981) Near-UV radiation effects on microorganisms Photochem Photobiol 34:761-768

Jagger J (1983) Physiological effects of near-ultraviolet radiation on bacteria. Photochem Photobiol Rev 7:1-75

Jerlov NG (1968) Optical oceanography. Elsevier Publishing, Amsterdam

Jones RD, Hood MA (1980) Effects of temperature, pH, salinity and inorganic nitrogen on the rate of ammonium oxidation by nitrifiers isolated from wetland environments. Microb Ecol 6:339-347

Jones RD, Morita RY (1984) Effect of several nitrification inhibitors on carbon monoxide and methane oxidation by ammonium oxidızers. Can J Microbiol 30:1276-1279

Jones RD, Morita RY (1985) Low-temperature growth and whole-cell kinetics of a marine ammonium oxıdızer. Mar Ecol Prog Ser 21:239-243

Jones RD, Morita RY, Koops HP, Watson SW (1988) A new marine oxidizing bacterium, Nitrosomonas cryotolerans sp. nov. Can J Microbiol 34:1122-1128

Loveless JE, Painter HA (1968) The influence of metal ion. concentration and $\mathrm{pH}$ value on the growth of a Nitrosomonas strain isolated from activated sludge. J Gen Microbiol 52:1

Müller-Neuglück $M$, Engel $H$ (1961) Photoinaktivierung 
von Nitrobacter winogradskyi Buch. Arch Mikrobiol 39 $130-138$

Navarro E, Fernandez MP, Grimont F, Clays-Josserand A, Bardin R (1992) Genomic heterogeneity of the genus Nitrobacter. Int J Syst Bacteriol 42:554-560

Nomoto T, Fukumori Y, Yamanaka T (1993) Membranebound cytochrome $c$ is an alternative electron donor for cytochrome $a a_{3}$ in Nitrobacter winogradskyi. J Bacteriol $175: 4400-4,404$

Olson RJ (1981) Differential photoinhibition of marine nitrifying bacteria: a possible mechanısm for the formation of the primary nitrite maximum. J Mar Res 39: $227-238$

Schön G, Engel H (1962) Der Einfluß des Lichtes auf Nitrosomonas europaea Win. Arch Microbiol 42:415-428

This article was submitted to the editor
Smith AJ, Hoare DS (1968) Acetate assimilation by Nitrobacter agilis in relation to its 'obligate autotrophy' J Bacteriol 95:844-855

Vanzella A, Guerrero MA, Jones RD (1989) Effect of CO and light on ammonium and nitrite oxidation by chemolithotrophic bacteria. Mar Ecol Prog Ser 57:69-76

Watson SW, Waterbury JW (1971) Characteristics of two marine nitrite oxidizing bacteria, Nitrospina gracilis nov. gen. nov sp. and Nitrococcus mobilis nov. gen. nov. sp. Arch Microbiol 77:203-230

Yoshioka T Saijo $Y(1984)$ Photoinhibition and recovery of $\mathrm{NH}_{4}{ }^{+}$-oxidizing bactena and $\mathrm{NO}_{1}{ }^{-}$-oxidizing bacterna. J Gen Appl Microbiol 30:151-166

Zafiriou OC, True MB (1979) Nitrite photolysis in seawater by sunlight. Mar Chem 8:9-32

Manuscrupt first received: April 25, 1996

Revised version accepted: June 5, 1996 